\title{
Meningkatkan Kemampuan Keaksaraan Anak dengan Permainan Balok Geometri Huruf
}

\author{
Siti Nurrohmah \\ nuur_lies@yahoo.com \\ TK Masyithoh Dukuh Imogiri Bantul
}

\begin{abstract}
Abstrak
Dunia anak adalah dunia bermain. Anak menghabiskan sebagian besar waktunya untuk bermain. Sebagian anak merasa senang dan tertarik dengan permainan balok. Anak-anak bermain menyusun balok-balok menjadi berbagai bentuk bangunan. Selain mengembangkan kemampuan kognitif dan kreativitas, balok juga dapat digunakan untuk mengembangkan aspek keaksaraan dengan membuat balok geometri huruf. Balok geometri huruf memanfaatkan bentuk-bentuk geometri seperti persegi panjang, kotak, lingkaran, setengah lingkaran, dan bentuk tertentu yang digunakan untuk mengenalkan dan meingkatkan kemampuan keaksaraan anak. Balok geometri huruf terdiri dari dua jenis, yakni balok geometri huruf kecil dan balok geometri huruf besar.Balok geometri memiliki jenis, ukuran, dan jumlah tertentu. Setiap set huruf memiliki semua unsur balok pembentuk huruf alfabetis dari a hingga $\mathrm{z}$.
\end{abstract}

Kata kunci: meningkatkan, kemampuan keaksaraan, balok geometri huruf

\section{Abstract}

Children's world is playing. Children spend most of their time for playing. Some children like and are interested in playing block games. Children make many kinds of building from blocks. Besides developing cognitive ability and creativity, blocks are also usable for developing the children's literacy aspect by making letter geometric blocks. Letter geometric blocks use geometrical shapes like rectangle, cubes, circles, crescent, and certain shapes that are used to introduce and improve children's literacy ability. There are two kinds of letter geometric blocks, namely, little letter geometric blocks and capital letter geometric blocks. Geometric blocks have various types, sizes, and certain numbers. Each set of letters has all elements of alphabetic letter blocks from a to $\mathrm{z}$.

Keywords: improving, literacy ability, letter geometric blocks

\section{Latar Belakang}

Masa anak-anak adalah senang dengan permainan. Mereka senang dengan permainan balok-balok, menyusun balok-balok menjadi berbagai bentuk bangunan. Kenyataan yang ada di lapangan bahwa anak belum memperoleh permainan sesuai dengan karakter anak, sehingga anak-anak merasa bosan dengan pelajaran yang diajarkan selama ini.Karena kurangnya pengetahuan para guru untuk selalu belajar inovatif sehingga metode yang digunakan kurang tepat.

Dalam kurikulum 2010, bidang pe- 
ngembangan berbahasa terdapat bahan khusus mengenai keaksaraan, hal ini menunjukkan bahwa keaksaraan memang perlu diajarkan pada anak mulai dari usia dini, sehingga anak bisa mengerti keaksaraan dan bisa membaca huruf. Melalui permainan geometri huruf ini anak-anak bisa membaca sesuai dengan usia anak-anak TK serta harapan dari orang tua, guru, pemerintah bisa tercapai.

Berdasarkan penelitian yang dilakukan di TK Masyithoh Dukuh Imogiri kelompok A2, mulai tanggal 1 September-1 November 2011 anak-anak senang dengan permainan balok. Peneliti mencoba untuk melakukan penelitian "permainan geometri huruf", diharapkan anak-anak tertarik dengan permainan ini dan akhirnya anak dapat membaca sesuai dengan harapan guru dan orang tua.

\section{Pengertian Keaksaraan}

Sebelum lebih lanjut kita membahas masalah tentang permainan "geometri huruf" kita pahami dulu apa arti keaksaraan. Keaksaraan adalah kemampuan memahami bentuk yang dapat dibaca, kurikulum TK (2010:49)

\section{Pengertian Permainan Geometri Huruf}

Geometri huruf merupakan permainan memanfaatkan bentuk-bentuk geometri seperti persegi panjang, kotak, lingkaran, setengah lingkaran, dan bentuk tertentu. Bentuk-bentuk tersebut memiliki ukuran tertentu sehingga dapat digunakan untuk membentuk huruf standar. Selama kegiatan permainan ini, anak-anak dapat membuat satu set kontruksi huruf dari keeping geometri yang berjumlah 21 untuk huruf kapital dan 19 jenis keping geometri untuk huruf kecil. Setiap jenis memiliki 1 hingga 17 keping.Keping tersebut ditata hingga membentuk huruf tertentu.

Permainan geometri huruf dapat digunakan untuk mendeteksi kemampuan konstruksi anak terhadap huruf dengan memanfaatkan daya imajinasi dan visuo- spasial. Anak yang sudah mengenal huruf relatif mudah menyusun dalam geometri huruf.

Permainan geometri huruf dilatarbelakangi oleh hasil pengamatan di KB dan TK, sebagai berikut:

a. Anak-anak memiliki minat yang tinggi terhadap balok.

b. Huruf-huruf, sebenarnya, terdiri atas bentuk-bentuk geometri yang tertata.

c. Bentuk geometri belum dimanfaatkan sebagai alat permainan keaksaraan.

d. Permainan keaksaraan dengan menggunakan balok (dalam hal ini keping geometri) berarti mengaktifkan otak kanan.

Berdasarkan kondisi awal tersebut dibuatlah permainan geometri huruf untuk anak dengan kriteria berikut:

a. Menantang anak untuk memanfaatkan kemampuan kontruksi dan imajinasi.

b. Merangsang anak untuk memperhatikan unsur huruf berdasarkan keping-keping pembangunnya.

c. Sesuai dengan tingkat perkembangan membaca anak.

d. Bertujuan untuk persiapan anak membaca dan mengenali fitur huruf.

Berdasarkan kondisi awal dan kriteria di atas maka dibuatlah permainan geometri huruf dengan argumentasi berikut:

a. Permainan geometri huruf merangsang kemampuan kontruksi dan imajinasi anak dalam menata dan menyusun bentuk-bentuk geometri secara horizontal.

b. Permainan geometri huruf merangsang anak untuk memerhatikan dan bereksperimen dengan kepingkeping huruf guna membentuk huruf-huruf, baik benar ataupun salah.

c. Permainan geometri huruf merangsang perkembangan keaksaraan anak sesuai denganminatdan tahap perkembangannya.

d. Permainan geometri huruf dapat dimanfaatkan sebagai persiapan anak membaca melalui proses bottom up berdasarkan fitur-fitur huruf. 


\section{Permainan Geometri Huruf}

a. Unsur Balok Geometri

Balok geometri huruf terdri dari dua jenis, yakni balok geometri huruf kecil dan balok geometri huruf besar.Balok geometri memiliki jenis, ukuran, dan jumlah tertentu. Setiap set huruf memiliki semua unsur balok pembentuk huruf alfabetis dari a hingga $\mathrm{z}$.

Geometri huruf kecil memiliki 19 jenis balok dan berjumlah 51 keping, terdiri 10 balok berpasangan dan 9 bentuk tunggal. Balok berpasangan, meliputi 7 balok panjang, 6 setengah lingkaran, 6 lengkung, 5 balok panjang sedang, 4 balok panjang lancip, 4 balok kubus kecil, 3 balok boomerang, 33 balok lengkung, 2 balok penyangga, 2 balok panjang kecil. Balok tunggal terdiri dari 4 huruf utuh (a, e, o, s), 5 balok tunggal (trapesium, belah ketupat panjang, belah ketupat kecil, seperangkat lingkaran, dan segiempat tipis)

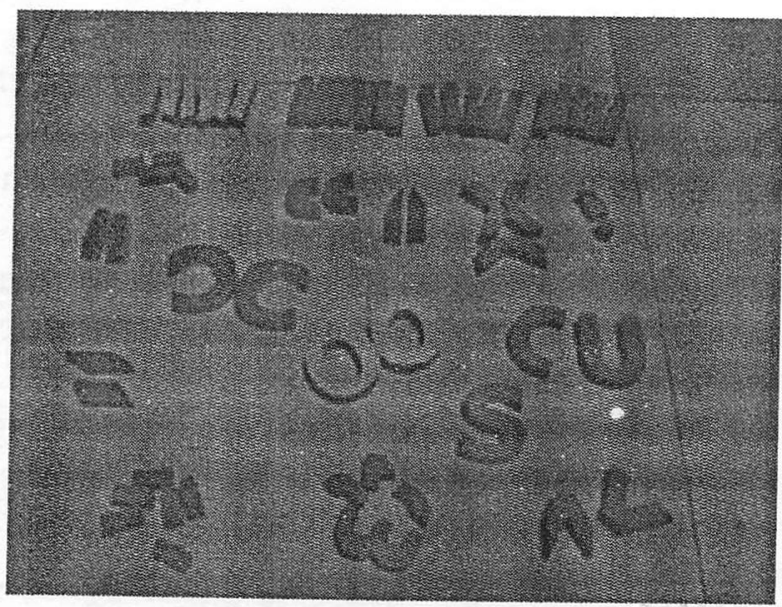

Gambar 1: Unsur Balok Geometri

Balok-balok tersebut telah memiliki kesesuaian bentuk antara satu bentuk dengan yang lain sehingga dapat dirangkai menjadi huruf-huruf tertentu.

\section{b. Komposisi Balok}

Komposisi balok tidaklah isolatif, kecuali huruf s, o, e, a, dalam balok geometri huruf kecil. Hal ini berarti, setiap balok hakekatnya berpasangan maupun berkawanan (memiliki lebih dari satu pasang). Berpasangan seperti balok dan setengah lingkaran demi membentuk huruf b, d, p, dan q, se- bagaimana ditunjukkan contoh berikut ini.

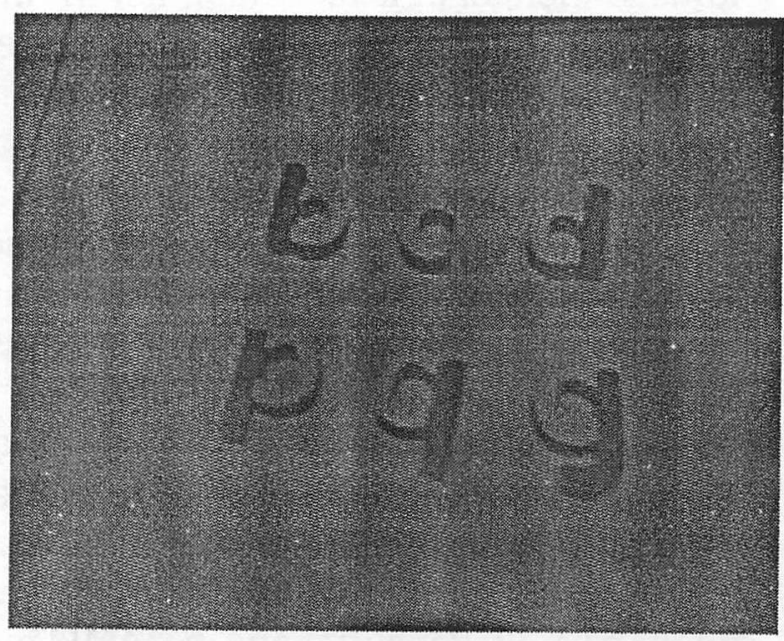

Gambar 2: Komposisi Balok

Apabila melihat komposisi balok yang dibuat anak, dapat dibuat kategori sebagai berikut:

a. Komposisi Acak

Komposisi ini dibuat anak dengan memasangkan balok-balok tanpa rujukan ke huruf. Anak hanya menata sekehendak hatinya. Bentuk tersebut mungkin berubah-ubah sesuai keing-inan anak. Anak mungkin menggabungkan setengah lingkaran dengan setengah lingkaran.

b. Komposisi Metatesis

Komposisi metatesis sudah mulai mengarah ke bentuk tertentu.Anak sudah memiliki konsep tentang huruf tetapi masih mengalami kesulitan mengonstruk dengan betul. Beberapa bentuk yang dibuat anak berbentuk huruf sebagian masih tertukar bahkan acak.

c. Komposisi Konvensional

Komposisi konvensional merupakan konstruk huruf yang sudah benar.Anak dapat menata balok-balok geometri menjadi huruf-huruf dari a hingga $\mathrm{z}$. Komposisi ini diperoleh melalui latihan yang berulang-ulang. Para pendidik pun dapat mencapai komposisi ini setelah melakukan latihan beberapa kali. Setelah melalui proses latihan komposisi balok akan menjadi sebagai berikut: 


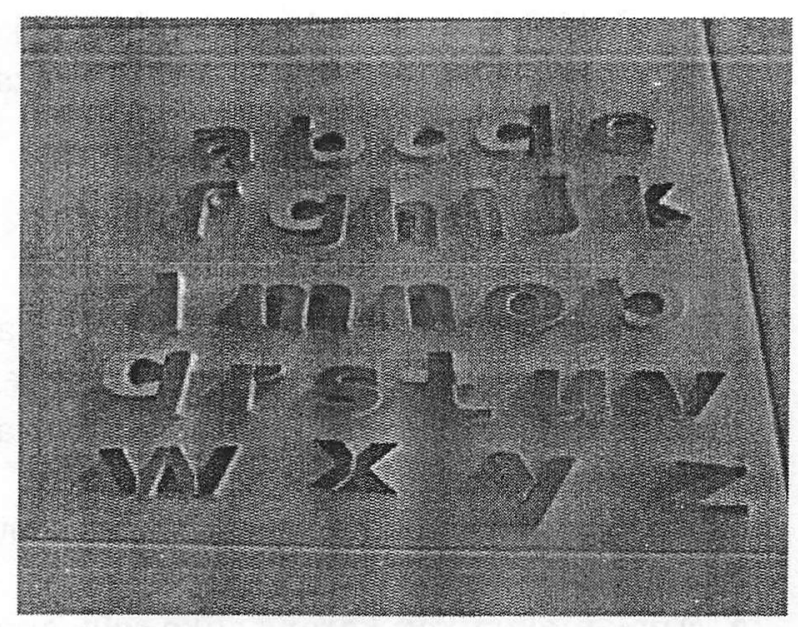

Gambar 3: Komposisi Konvensional

\section{Tahap Pemerolehan Bahasa Tulis Reseptif}

Dalam buku menumbuhkembangkan baca tulis anak usia dini Musfiroh (2009: 28-36) menjelaskan bahwa tahap pemerolehan bahasa tulis reseptif anak diketegorikan ke dalam enam tahap, yang tiap tahap mungkin terdiri dari 2 atau 3 sub tahap:

1. Tahap Diferensiasi

Pada tahap ini anak memperhatikan tulisan dan membedakannya dengan gambar. Anak dapat menyebut gambar sebagai gambar dan tulisan sebagai tulisan.

2. Tahap membaca pura-pura

a. Tahap Atensi Bahasa Tulis

Anak memerhatikan berbagai model tulisan diberbegai media yang dihat dan tertarik dengan bentuk tulisan tertentu. Anak menyukai buku cetak dan membawa kesana kemari.

b. Tahap Membaca Diskursif

Anak mengetahui bahwa tulisan dapat dilafalkan dan memiliki informasi.

3. Tahap Membaca Gambar

Anak memperhatikan tanda-tanda visual seperti gambar tetapi belum menguasai simbol. Anak "membaca" koran dengan melihat gambar, membaca label dengan memperhatikan barang dan gambarnya. Anak menjabarkan gambar/informasi visual lain dalam bentuk satu kalimat atau lebih.Pada tahap membaca gambar, pendidik pendidik perlu melakukan stimulasi pada anak yang bermula pada interpretasi anak terhadap gambar.

4. Tahap Membaca Acak

a. Tahap Membaca Acak Total

Anak menanyakan tulisan yang menarik perhatiannya, seperti label, nama judul. Anak memperhatikan gaya tulisan, warna tulisan, dan fiturfitur lainnya. Anak dapat mengenal kembali tulisan tersebut. Apabila menemukan tulisan yang dikenal, anak membaca kata tersebut dan menebak tulisan selanjutnya.Anak membaca " Harian Republika" sebagai "Koran Republika", karena anak mengenal kembali kata Republika. Anak sudah mengidentifikasi huruf awal

b. Tahap Membaca Semi Acak

Ketertarikan anak terhadap tulisan di televisi (nama stasiun TV), nama tokoh, nama majalah, merk sepatu, merk alat-alat elektronik sangat terlihat. Anak aktif bertanya dan cepat mengenali tulisan.Pada tahap ini anak mungkin mengira kalau kata tertentu mengacu pada benda tertentu. Anak terkejut katika mendapati kata sony pada pembungkus kaos dalam, padahal mengenali tulisan sony pada kamera dan televisi. Anak mengenal huruf dan mencoba menggabungkannya menjadi suku kata meskipun kadang belum tepat.

5. Tahap Lepas Landas

Tahap lepas landas terbagi atas tiga sub tahap, yakni tahap mengeja huruf lepas, tahap mengeja silabel-kata, dan tahap membaca lambat tanpa nada. Setiap sub tahap ditandai oleh indikator yang tipis tetapi dapat dirasakan perbedaannya.

a. Tahap Mengeja Huruf Lepas

Anak dapat membaca dengan mengeja kata-kata yang belum dikenal sebelumnya. Anak dapat menggabungkan huruf menjadi suku kata terbuka (tetapi terhambat dalam suku kata tertutup). Pada tahap ini anak sudah mulai memiliki minat pada buku cerita, simbol-simbol di sekitarnya. Anak 
membaca apa saja yang ada di sekitarnya walaupun sering frustasi ketika perhatiannya terlalu terfokus pada huruf lepas.

b. Mengeja Silabel-Kata

Anak dapat membaca dengan mengeja kata-kata baru. Anak dapat menggabungkan suku kata menjadi kata. Anak bisa mengeja suku terbuka tetapi lambat dalam suku kata tertutup. Pada tahap ini, anak-anak sangat peka terhadap kata-kata yang dikenal, terutama apabila kata tersebut mirip atau mengandung namanya.

c. Membaca Lambat Tanpa Nada Anak dapat membaca teks baru secara lambat tetapi relativ cepat untuk kata yang sudah dikenal.Anak mungkin berhenti beberapa saat pada kata baru yang belum dikenal (bentuk maupun maknanya). Anak tidak langsung dapat memahami apa yang dibaca, tetapi pengulangan dapat membantu mereka memahami tulisan pendek. Sementara itu, lagu kalimat juga belum diperoleh secara alamiah.Anak masih berfokus pada pelafalan teks.

6. Tahap Independen

Riset menunjukkan bahwa tahap independen dapat dikategorikan ke dalam dua tahap, yakni independen awal dan independen.

a. Tahap Independen Awal

Hasil bacaan masih lambat, tetapi anak dapat memahami apa yang dibaca. Sudah ada lagu kalimat (koma dan titik), meeskipufi belum sempurna. Tahap ini dikenal sebagai tahap hampir sempurna.Tahap ini ditemukan pada sebagian kecil anak TK pedesaan dan beberapa anak TK perkotaan dengan fasilitas baca yang baik.

b. Tahap Independen

Hasil bacaan anak relativ cepat, sudah memiliki lagu dan nada yang tepat. Anak sudah menguasai komponen tanda baca dan makna teks juga sudah diperoleh. Fasilitas bacaan/buku cerita yang menarik dimanfaatkan secara aktif oleh anak. Beberapa teks singkat pada surat kabar atau majalah akan dibaca keras-keras oleh anak.

\section{Bermain}

Ciri-ciri bermain adalah:

a. Menyenangkan dan menggembirakan bagi anak, anak menikmati kegiatan bermain tersebut, mereka tampak riang dan senang.

b. Dorongan bermain muncul dari anak bukan paksaan dari orang lain.

c. Anak melakukan karena suka rela, anak tidak merasa diwajibkan.

d. Semua anak ikut serta secara bersamasama sesuai peran masing-masing

e. Anak berlaku pura-pura, atau memerankan sesuatu, anak pura-pura marah atau menangis

f. Anak menetapkan aturan main sendiri, baik aturan yang diadopsi dari orang lain maupun aturan yang baru, aturan main itu dipenuhi oleh semua peserta bermain.

g. Anak berlaku aktif, mereka melompat atau menggerakkan tubuh, tangan, dan tidak sekedar melihat.

h. Anak bebas memilih mau bermain apa dan beralih ke kegiatan bermain lain, bersifat fleksibel (Musfiroh, 2008:4).

Menurut Meyke ST melalui A Maruti (2008: 39-51) bermain memiliki manfaat:

a. Untuk perkembangan fisik

Kegiatan-kegiatan yang melibatkan gerakan tubuh akan membuat anak menjadi sehat, otot-otot tubuh akan menjadi kuat.

b. Untuk perkembangan aspek motorik Pada usia 1-5 tahun anak mulai belajar memegang pensil dan membuat coretan, secara tidak langsung ia belajar melakukan gerakan-gerakan motorik halus untuk menulis. Sementara motorik kasar akan berkembang melaui gerakan berjalan, meniti, berlari dan sebagainya.

c. Bermain untuk perkembangan aspek sosial

Bermain juga berperan sebagai media bagi anak-anak mempelajari budaya setempat, ia akan mewarisi permainan 
yang khas sesuai dengan budaya masyarakat tempat ia hidup. Dari sini ia akan belajar tentang system nilai, kebiasaankebiasaan dan standar moral yang dianut oleh masyarakat.

d. Bermain untuk perkembangan kepribadian dan emosi.

e. Bermain untuk perkembangan aspek kognitif.

f. Bermain untuk mengasah ketajaman pengindraan.

g. Bermain untuk mengembangkan keterampilan olah raga dan menari.

\section{Metode Penelitian}

Penelitian yang dilakukan adalah jenis penelitian tindakan kelas.Dalam penelitian ini melibatkan kolaborator untuk membantu mengamati kegiatan belajar untuk mendapatkan data yang lebih akurat. Penelitian ini dilakukan di TK Masyithoh Dukuh yang berlokasi di Dukuh, Imogiri, Imogiri, Bantul, sebelah barat kecamatan Imogiri.

\section{Prosedur Penelitian}

Prosedur penelitian terdapat empat tahapan yang lazim dilalui, yaitu (1) perencanaan (Planning), (2) Tindakan (Acting), (3) Pengamatan (Observing), Refleksi (Reflecting). (PTK Suharsimi Arikunto: 16). Divisualisasikan dalam bentuk gambar, penelitian model ini tampak dalam gambar berikut ini:

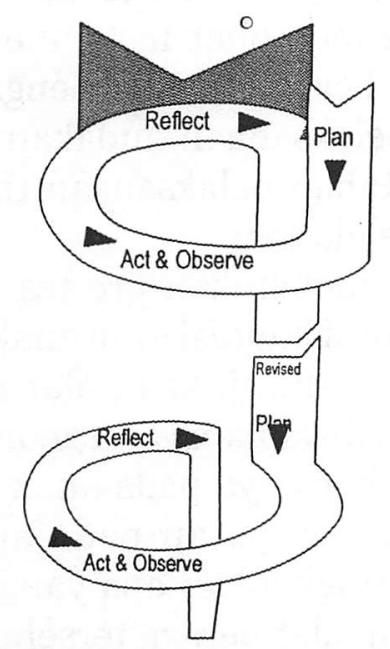

Gambar 1

Penelitian Tindakan menurut Kemmis \& Mc Taggart (1988)
Data awal yang peneliti lakukan masih dalam tahap membaca deferensiasi yaitu membaca gambar, dengan tindakan yang ingin kami rancang ini diharapkan akan dapat meningkat menjadi tahapan independen.

Adapun tindakan yang kami rencanakan adalah sebagai berikut:

1. Tahap 1

Guru memperkenalkan berbagai macam bentuk-bentuk geometri yang dapat dirangkai menjadi bentuk huruf. $\mathrm{Hal}$ ini dapat diulang beberapa kali serta dilakukan sambil bernyanyi.

2. Tahap 2

Guru memperkenalkandan memberi contoh permainan yang akan dilakukan pada saat itu yaitu dengan cara menebar acak bentuk-bentuk geometri, kemudian anak-anak disuruh merangkai jadi bentuk huruf, lanjutkan menyusun menjadi kata dan disuruh untuk membacanya.

\section{Subyek, Tempat dan Waktu Penelitian}

Penelitian ini dilakukan oleh peneliti di TK Masyithoh Dukuh, Imogiri, Bantul. Subyek penelitian ini adalah anak kelompok A2, dengan jumlah 20 anak, 9 orang anak lakilaki, 11 orang anak perempuan. Penelitian ini dilakukan mulai tanggal 1 Oktober sampai 31 Desember 2011.

\section{Instrumen Penelitian}

Dalam penelitian ini instrument yang peneliti gunakan adalah:

1. Lembar observasi/pengamatan

Lembar obsevasi ini sangat diperlukan untuk mengamati kerja anak yang sedang berlangsung, selain itu juga untuk mengamati perkembangan interaksi sosial anak, dan perkembangan motorik anak.

2. Lembar kerja

Lembar kerja ini digunakan untuk melihat hasil kerja anak secara nyata, karena dengan mengamati hasil kerja anak dapat diketahui perkembangan keaksaraan anak. 


\section{Teknik Pengumpulan Data}

Untuk membantu mengumpulkan data yang akurat, peneliti menggunakan alat pengumpul data antara lain wawancara tidak terstruktur, observasi, unjuk kerja, dan dokumentasi berupa foto-foto pelaksanaan kegiatan.

\section{Analisis Data}

Teknik analisis data yang dipakai adalah menggunakan teknik statistik deskriptif yaitu mengolah karakteristik data yang berkaitan dengan menjumlah, merata-rata, mencari titik tengah, mencari persentase, dan menyajikan data yang menarik, mudah dibaca, dan diikuti alur berfikirnya (grafik, tabel, chart) (Supardi,2006: 131-132). Rencana tindakan adalah gambaran tentang langkah-langkah riil yang akan dilakukan dalam tindakan (Suharsimi: 39) sesuai dengan prosedur peneliti, kami lakukan penelitian ini melalui dua siklus tindakan. Pada setiap siklus dilakukan dalam tiga kali pertemuan. Apabila hasilnya belum memuaskan maka siklus dapat ditambah lagi, tapi apabila sudah cukup memuaskan, siklus tindakan tidak perlu ditambah.

\section{Hasil Penelitian}

Siklus 1 dilaksanakan 3 kali pertemuan dengan 4 tahapan yaitu:

a. Perencanaan

Pada tahap perencanaan ini yang dilakukan penelitiadalah:

1. Guru membuat persiapan mengajar

2. Guru menyiapkan media pembelajaran yaitu geometri huruf

3. Guru membuat instrument evaluasi yaitu berupa lembar pengamatan

b. Tahap pelaksanaan tindakan

Dalam tahap pelaksanaan tindakan ini guru melakukan:

1. Guru melakukan pre tes untuk mengetahui kondisi awal anak

2. Guru menunjukkan alat peraga yag sudah disiapkan yaitu geometri huruf

3. Guru bertanya pada anak dan memberi kesempatan pada anak untuk mengungkapkan apa yang diketahui dengan alat peraga tersebut.

4. Guru memberi contoh menyusun geometri huruf

5. Anak disuruh menyusun geometri huruf

c. Tahap monitoring

Pada tahap ini dilakukan proses observasi dan monitoring terhadap pelaksanaan tindakan, yang perlu diamati yaitu:

1. Situasi belajar mengajar yang meliputi dari kegiatan awal sampai akhir pembelajaran dicatat dan didokumentasi oleh kolaborator untuk mengetahui peningkatan kemampuan keaksaraan membaca melalui permainan geometri huruf.

2. Guru mencatat hasil kerja anak ketika melaksanakan tugas.

d. Analisis dan Refleksi

Pada tahap ini merupakan hasil pengamatan pada kegiatan belajar mengajar dan memberikan tugas pada anak untuk melakukan kegiatan dengan alat peraga geometri huruf.

Siklus 2 dilaksanakan 3 kali pertemuan terdiri dari 4 tahapan seperti pada siklus 1 a. Tahap perencanaan

Tahap perencanaan ini yang dilakukan peneliti adalah:

1. Guru membuat persiapan mengajar

2. Guru menyiapkan media pembelajaran yaitu geometri huruf

3. Guru membuat instrument evaluasi yaitu berupa lembar pengamatan

b. Tahap pelaksanaan tindakan

Dalam tahap pelaksanaan tindakan ini guru melakukan:

1. Guru melakukan pre tes untuk mengetahui kondisi awal anak

2. Guru menunjukkan alat peraga yag sudah disiapkan yaitu geometri huruf

3. Guru bertanya pada anak dan memberi kesempatan pada anak untuk mengungkapkan apa yang diketahui dengan alat peraga tersebut.

4. Guru memberi contoh menyusun geometri huruf

5. Anak disuruh menyusun geometri 
huruf.

c. Tahap monitoring

Pada tahap ini dilakukan proses observasi dan monitoring terhadap pelaksanaan tindakan, yang perlu diamati yaitu:

1. Situasi belajar mengajar yang meliputi dari kegitan awal sampai akhir pembelajaran dicatat dan didokumentasi oleh kolaborator untuk mengetahui peningkatan kemampuan keaksaraan membaca melalui permainan geometri huruf.

2. Guru mencatat hasil kerja anak ketika melaksanakan tugas

d. Analisis dan Refleksi

Pada tahap ini merupakan hasil pengamatan pada kegiatan belajar mengajar dan memberikan tugas pada anak untuk melakukan kegiatan dengan alat

Tabel 1. Hasil Observasi Perkembangan Keaksaraan

\begin{tabular}{|c|c|c|c|c|c|c|c|c|c|}
\hline Variabel & \multicolumn{3}{|c|}{ Kondisi awal } & \multicolumn{3}{c|}{ Siklus 1 } & \multicolumn{3}{c|}{ Siklus 2 } \\
\hline & Tinggi & Sedang & Rendah & Tinggi & Sedang & Rendah & Tinggi & Sedang & Rendah \\
\hline $\begin{array}{c}\text { Partisipasi dan } \\
\text { interaksi sosial }\end{array}$ & 48 & 126 & 41 & 84 & 170 & 7 & 237 & 82 & - \\
\hline $\begin{array}{c}\text { Perkembangan } \\
\text { Bahasa Tulis } \\
\text { Produktif }\end{array}$ & - & 24 & 9 & 9 & 30 & 6 & 48 & 9 & 3 \\
\hline $\begin{array}{c}\text { Keaksaraan } \\
\text { Reseptif }\end{array}$ & 3 & 22 & 11 & 24 & 28 & 3 & 51 & 6 & 2 \\
\hline $\begin{array}{c}\text { Permainan } \\
\text { Geometri huruf }\end{array}$ & 84 & 92 & 6 & 141 & 70 & - & 195 & 30 & - \\
\hline
\end{tabular}

peraga geometri huruf.

\section{Kesimpulan}

Berdasarkan hasil penelitian yang dilakukan pada anak TK Masyithoh Dukuh Imogiri Imogiri Bantul kelompok A2 semester I tahun pelajaran 2011/2012 peningkatan kemampuan keaksaraan melalui permainan geometri huruf adalah sebagai berikut: peningkatan partisipasi dan interaksi sosial meningkat $43 \%$, perkembangan bahasa tulis produktif meningkat $60 \%$, perkembangan keaksaraan reseptif meningkat $44 \%$, perkembangan permainan geometri huruf meningkat $21 \%$, perkembangan minat baca meningkat $19 \%$, dan perkembangan keaksaraan meningkat $37 \%$.

\section{Daftar Rujukan}

Departemen Nasional. 2005. Kurikulum $T K / R A$. Jakarta: Depdikbud

Departemen Pendidikan Nasional. 2007. Pedoman Pembelajaran Bidang Pengembangan Bahasa di TK. Jakarta: Direktorat Pembinaan TK dan

Depdiknas. 2010. Kurikumum TK dan RA Standar Kompetensi.Jakarta: Depdiknas

Suharsimi Arikunto. 2006. Penelitian Tindakan Kelas. Jakarta: Rineka Cipta . 1998. Prosedur

Penelitian. Jakarta: Rineka Cipta

Tadkiroatun Musfiroh. 2011. Menumbuhkembangkan Baca Tulis Anak Usia Dini. Makalah Diktat Baca Tulis. Lemlit UNY. 